\title{
The usefulness of non-directed bronchoalveolar lavage in diagnosis pneumonia in ICU
}

\author{
T Zawada*, J Bartczak, M Kozak, A Wieczorek, P Garba \\ From ESICM LIVES 2015 \\ Berlin, Germany. 3-7 October 2015
}

\begin{abstract}
Introduction
Intensive care units are high-risk areas for infections caused by antibiotic-resistant bacteria. Care of ICUs patients involve close contact with hospital staff and provide opportunities for cross-contamination from the environment and from other patients. The resulting colonization of patients is generally accepted as a prerequisite for causing most of nosocomial infections including hospital - aquired pneumonia and VAP. Information about microorganism which cause particular infections and colonization in ICU is essential to prepare local antibiotic guidelines and should be taken into account in implementing empirical treatment.
\end{abstract}

\section{Objectives}

The aim of the study was to create ICU's microbiological map of pneumonia based on specimens received from non-directed bronchoalveolar lavage.

\section{Methods}

We analyzed the results of the non-directed bronchoalveolar lavage (NBL) collected from patients hospitalized in the ICU during last 5 years. Every patient admitted to the ICU had NBL taken and was categorized to one of three groups: no infection, colonization (colony forming $<10^{2}$ units $/ \mathrm{mL}$ ), pneumonia (colony forming $\geq 10^{3}$ units $/ \mathrm{mL}$ ). We analyzed the types of bacteria which caused colonization or pneumonia and their antibiotic-sensitivity.

\section{Results}

See tables 1, 2 and 3.

\section{Conclusions}

The NBL is a useful method to identify infection and colonization of lower airways. It allows to create

4 WSK z Poliklinika we Wroclawiu, Wrocław, Poland
Table 1. Results of the NBL performed on the admission

\begin{tabular}{llll}
\hline & $\begin{array}{l}\text { NO } \\
\text { INFECTION }\end{array}$ & COLONIZATION & PNEUMONIA \\
\hline $\begin{array}{l}\text { NUMBER OF PATIENTS } \\
(\%)\end{array}$ & $679(45,5 \%)$ & $409(27,5 \%)$ & $400(27 \%)$ \\
\hline
\end{tabular}

Table 2. Identification of microorganisms caused pneumonia

\begin{tabular}{ll}
\hline S. baumani & \% of isolation \\
\hline S. aureus & $31,5 \%$ \\
\hline P. aeruginosa & $13,4 \%$ \\
\hline E. coli & $13,1 \%$ \\
\hline K. pneumoniae & $9,2 \%$ \\
\hline C. albicans & $8,6 \%$ \\
\hline E. faecalis & $7,2 \%$ \\
\hline S.pneumoniae & $5,3 \%$ \\
\hline S.oralis, E. Faecium & $4,5 \%$ \\
\hline
\end{tabular}

Table 3. Antibiotic - sensitivity of A.baumani

\begin{tabular}{llll}
\hline Medicine & susceptible(\%) & intermedate (\%) & resistant (\%) \\
\hline Collistin & $99 \%$ & $0 \%$ & $1 \%$ \\
\hline Meropenem & $33 \%$ & $12 \%$ & $55 \%$ \\
\hline Imipenem & $36 \%$ & $22 \%$ & $42 \%$ \\
\hline Gentamycin & $58 \%$ & $0 \%$ & $42 \%$ \\
\hline
\end{tabular}

microbiological map of ICU's residual pathogens and their drug sensitivity, and as a consequents gives intensivist opportunity to implement suitable antibiotic treatment.

Grant Acknowledgment ICU Staff

Published: 1 October 2015 


\section{References}

1. UK Standards for Microbiology Investigations: Investigation of

Bronchoalveolar Lavage, Sputum and associated Specimens, Bacteriology/ B57/No.25/02.06.2014.

2. Bhattacharya S, Mondal AS: Clinical microbiology in the intensive care unit: Strategic and operational characteristics. Indian J Med Microbiol 2010, 28(1):5-10, Jan-Mar.

3. Chastre J, Fagon JY: Invasive diagnostic testing should be routinely used to manage ventilated patients with suspected pneumonia. Am J Respir Crit Care Med 1994, 150:570-574.

4. Guidelines for the Management of Adults with Hospital-acquired, Ventilatorassociated, and Healthcare-associated Pneumonia: Am J Respir Crit Care Med 2005, 171:388-416.

doi:10.1186/2197-425X-3-S1-A711

Cite this article as: Zawada et al:: The usefulness of non-directed

bronchoalveolar lavage in diagnosis pneumonia in ICU. Intensive Care

Medicine Experimental 2015 3(Suppl 1):A711.

\section{Submit your manuscript to a SpringerOpen ${ }^{\odot}$ journal and benefit from:}

- Convenient online submission

- Rigorous peer review

- Immediate publication on acceptance

- Open access: articles freely available online

- High visibility within the field

- Retaining the copyright to your article

Submit your next manuscript at $>$ springeropen.com 